\title{
Effect of holding period prior to storage on the chemical attributes of Starking Delicious apples during refrigerated storage
}

\author{
Efeito do período que antecede o armazenamento nos atributos químicos de maças Starking Delicious \\ durante o armazenamento refrigerado
}

\author{
Aynur BATKAN ${ }^{1}$, Akif KUNDAKÇI ${ }^{1}$, Bülent ERGÖNÜL ${ }^{1 *}$
}

\begin{abstract}
In this research, the effects of three different holding periods $(6,12$ and 24 hours $)$ prior to storage on the quality attributes of Starking Delicious apples were investigated during storage of 8 months at $0.5 \pm 1.0^{\circ} \mathrm{C}$. Changes in weight loss, flesh firmness, $\mathrm{pH}$ values, soluble dry matter amount, titratable acidity values, ascorbic acid contents, and total and reducing sugar content were determined. According to the results, the holding period showed statistically significant changes in the quality attributes of the apples $(\mathrm{p}<0.05)$.

Keywords: apple; storage; quality.
\end{abstract}

\section{Resumo}

Neste trabalho, os efeitos de três diferentes tempos de espera (6, 12 e 24 horas) antes do armazenamento sobre os atributos de qualidade de maçãs tipo Starking Delicious foram investigados durante o armazenamento de 8 meses a $0,5 \pm 1,0{ }^{\circ} \mathrm{C}$. Alterações na perda de peso, firmeza da polpa, valores de $\mathrm{pH}$, quantidade de matéria seca solúvel, valores de acidez titulável, teor de ácido ascórbico e teor de açúcar redutor e total das amostras foram determinadas. De acordo com os resultados da análise, o tempo de espera causou alterações estatisticamente significativas sobre as nos atributos de qualidade das maçãs $(\mathrm{p}<0,05)$.

Palavras-chave: maçã; armazenamento; qualidade.

\section{Introduction}

Apple (Malus domestica Borkh), a fruit of warm climate regions, is widely consumed in many countries of the world (BURAK; BÜYÜKYILMAZ; ÖZ, 1998). Every year, approximately 60 million $t$ of apples are produced worldwide. Turkey produces about 2.5 million $t$ of apples every year. The main varieties which are produced in Turkey are Amasya, Starking Delicious, and Golden Delicious (TÜRKÍYE, 2004).

Starking Delicious apples, known as table apples in Turkey, have a thick and yellow skin and a short stem, a yellowish-white and soft flesh, and an aromatic taste and odor. Apples belonging to Starking Delicious variety are harvested in September and October and then stored for winter consumption (GÜNEL; KARAÇALI, 1985; ÖZBEK, 1978; KAYNAŞ, 1987).

One of the important factors that directly affect the quality of fruits is maintaining an effective cold chain system while transporting and storing them. In case of inadequate transporting and storage activities, there may be seen quality losses up to 30-40\% (ÖZELKÖK et al., 1992).

Factors affecting the storage life of apple are known as variety, region, horticultural activities, climatic conditions, maturity level at harvest, and storage conditions (LUTZ; HARDENBURG, 1977). It was reported that one fourth of the apples are spoiled worldwide before being consumed (SALUNKHE, 1974). It is very important to minimize the metabolic activities of apple during storage, transportation, and marketing to preserve them effectively without any changes in their quality and preventing spoilage (ÖZELKÖK et al., 1992). Decomposition of nutrients follows harvest due to respiration of the fruit. Thus, it is important to minimize the respiration rate in order to increase the storage period of fruits (ERTAN et al., 1992). Hence, harvested fruits should be taken into refrigerated storage immediately after harvesting. The rate of respiration decreases when temperature decreases and prolong the storage life of apples.

To lower the temperature of the fruit immediately after harvesting, pre-cooling should be done (ÖZ; BULAGAY, 1986). Pre-cooling is of fundamental importance in terms of keeping the quality and preventing the postharvest losses (KARAÇALI, 1993). Ice-water mixtures are used in order to cool down the apples prior to refrigerated storage.

For effective apple storage, the temperature of the cold rooms should be between 0 and $+4{ }^{\circ} \mathrm{C}$, whereas the relative humidity should be $85-90 \%$ (PEKMEZCİ, 1975). According to Kundakçı (1989), apples could be properly stored from -1 to $0{ }^{\circ} \mathrm{C}$ and under $90-92 \%$ relative humidity without any loss of quality.

The aim of this research is to determine the effect of the period between harvest date and the beginning of cold storage

${ }^{1}$ Food Engineering Department, Engineering Faculty, Celal Bayar University, Muradiye Campus, 45140, Manisa, Turkey, e-mail: bulent.ergonul@bayar.edu.tr

${ }^{*}$ Corresponding author 
on the quality attributes of Starking Delicious apples during storage at $0.5 \pm 1{ }^{\circ} \mathrm{C}$ and under $90 \pm 1 \%$ relative humidity.

\section{Materials and Methods}

Starking Delicious apples were harvested from 8 apple trees in an apple garden in Denizli, Turkiye. After harvesting, the apples were divided into four groups, and the apples from one of the groups were immersed in ice-water mixture and immediately transported to refrigerated storage rooms. This group of apples was named as control samples. The other 3 groups were held for different holding periods of 6,12 , and 24 hours and were named as A-6, A-12, and A-24, respectively. After the holding periods, the apples were placed in refrigerated storage. The apples were held prior to storage in an apple garden at approximately $29 \pm 2{ }^{\circ} \mathrm{C}$. The apples were stored in a refrigerated storage room at $0.5 \pm 1{ }^{\circ} \mathrm{C}$ and under $90 \pm 1 \%$ relative humidity. This procedure was performed in quadruplicate.

During the cold storage of 8 months, weight loss, apple flesh firmness, amount of soluble dry materials, titratable acidity, $\mathrm{pH}$ value, ascorbic acid content, reducing sugar, and total sugar content were determined with a 2 -month interval.

The flesh firmness of the samples was determined using an Instron universal testing machine Model J 140 with a probe of $11 \mathrm{~mm}$ diameter. 3 measurements were taken for each apple, and 5 apples were used for representing the each group. The amount of soluble dry matter was determined according to the refractometric method using an Abbe refractometer (2WAJ) (HOEHN et al., 2003).

The $\mathrm{pH}$ values of the samples were determined with the potentiometric method using a HI 9321 microprocessor $\mathrm{pH}$ meter (COSETENG; LEE, 2006). Total acidity of the samples was determined according to TS 1125 in terms of malic acid (HOEHN et al., 2003).

The ascorbic acid content of the samples was analyzed by a spectrophotometric method by using a spectrophotometer (UV-1601, Shimadzu) at wavelength of $500 \mathrm{~nm}$. Inverted and total sugar contents of the samples were determined by the Lane-Eynon method.

Statistical analysis of the data obtained from the research was performed at the Ege University Computer Engineering Department with the SAS 6.12 software. The Tukey test was performed using the SPSS 10.0 statistical software.

\section{Results and Discussion}

The results obtained from the analyses are shown in Table 1. As can be seen, the initial $\mathrm{pH}$ values of the samples, $\mathrm{C}, \mathrm{A}-6$, A-12, and A-24 were all determined as 3.77 just before they were taken into the storage rooms. It was determined that there were no differences between $\mathrm{pH}$ values of the samples from different groups of treatment. At the end of the second month of storage, the $\mathrm{pH}$ values of the samples increased up to $3.88,3.91,3.95$ and 4.00 , respectively, and it was seen that there were no statistically important differences between the $\mathrm{pH}$ values of the apples from different treatment groups $(\mathrm{p}>0.05)$. Nevertheless, storage time significantly affected the increase in the $\mathrm{pH}$ values of the samples at the end of the second month $(\mathrm{p}<0.05)$.

The $\mathrm{pH}$ values of all samples increased during the 8-month refrigerated storage, and at the end of the storage period, the $\mathrm{pH}$ values of $\mathrm{C}, \mathrm{A}-6, \mathrm{~A}-12$, and A-24 were recorded as 5.20, 5.25, 5.26 and 5.34, respectively. The $\mathrm{pH}$ values of the samples which were kept for longer holding time at ambient temperature prior to refrigerated storage were significantly higher than those of the other samples by the end of the refrigerated storage $(\mathrm{p}<0.05)$.

$\mathrm{Tu}$, Nicolar and De Baerdemaeker (2000) revealed that during refrigerated storage of apples, an increase in $\mathrm{pH}$ values was observed. According to Tu, Nicolar and De Baerdemaeker (2000), the initial $\mathrm{pH}$ values of Braeburn and Jonagld type apples were 3.47 and 3.38 respectively, whereas at the end of the 4 week-refrigerated storage, these values were found between 3.94 and 4.07. Koyuncu, Çavuşoğlu and Bakir (1997), Koyuncu, Eren and Dolunay (2003) and Konopacka and Plocharski (2004) determined that the $\mathrm{pH}$ value of different types of apples showed increase, whereas the total acidity showed decrease during storage in their studies. Our findings are similar to those found by them.

Water soluble dry matter amounts of C, A-6, A-12, and A-24 were determined as $12.15 \%$ for each sample at the beginning of the cold storage. During the first 4 months of storage, water soluble dry matter contents of A-6, A-12 and A-24 increased continuously followed by a decrease until the end of the storage period. Although the sugar content of the samples decreased with respiration, hydrolysis of starch, and the increase in the maltose and glucose contents, an increase was observed in the amount of soluble dry matter of the samples (KARAÇALI, 1993). The decrease seen after the $4^{\text {th }}$ month of storage resulted from the hydrolysis of sugar due to respiration and to water loss during storage.

Ertan et al. (1992) reported that average water soluble dry matter content of an apple at the beginning of the storage was $12.3 \%$, whereas this value was $14.2 \%$ at the $6^{\text {th }}$ month and $13.6 \%$ at the $9^{\text {th }}$ month of the storage.

According to the statistical analysis results, the holding period showed statistically significant changes in the amount of soluble dry matter of the samples $(\mathrm{p}<0.05)$

Flesh firmness is known as an important quality attribute for apples (PORRITT, 1976; RENFU et al., 2007). In the present study, it was determined that the holding period significantly affected the flesh firmness values of the samples during storage ( $p<0.05)$. According to Özcan (1990), the decrease in the flesh firmness values of the apples is due to the increase in solubility of protopectin because of enzymatic degradation and due to the decreased amount of protopectine. Due to high ambient temperature during the holding period prior to cold storage, the enzymatic activity and respiration rate increased, whereas the water content of the apples decreased. Abeles and Gahagan (1968) reported that respiration rate increased by a factor of 2-3 for every $10^{\circ} \mathrm{C}$ increase in ambient temperature. Therefore, with the increasing rate of metabolic activity, the storage life of the apples decreases. 
Table 1. Chemical attributes of Starking Delicious apple during refrigerated storage.

\begin{tabular}{|c|c|c|c|c|c|}
\hline & \multirow{2}{*}{$\begin{array}{l}\text { Storage time } \\
\text { (month) }\end{array}$} & \multicolumn{4}{|c|}{ Holding period (hour) } \\
\hline & & 0 & 6 & 12 & 24 \\
\hline \multirow{3}{*}{ Weight loss (\%) } & 2 & $0.98^{\mathrm{a}}$ & $1.01^{\mathrm{a}}$ & $1.01^{\mathrm{a}}$ & $1.02^{\mathrm{a}}$ \\
\hline & 4 & $1.05^{\mathrm{a}}$ & $1.13^{\mathrm{a}}$ & $1.14^{\mathrm{a}}$ & $1.13^{\mathrm{b}}$ \\
\hline & 8 & $3.63^{\mathrm{c}}$ & $3.66^{\mathrm{c}}$ & $3.62^{\mathrm{c}}$ & $4.02^{\mathrm{d}}$ \\
\hline \multirow{3}{*}{ Water soluble dry matter (\%) } & 0 & $12.15^{\mathrm{a} A * *}$ & $12.15^{\mathrm{aA}}$ & $12.15^{\mathrm{a} \mathrm{A}}$ & $12.15^{\mathrm{a} A}$ \\
\hline & 6 & $15.15^{\mathrm{b} A B}$ & $14.98^{\mathrm{bc} \mathrm{A}}$ & $16.15^{\mathrm{dC}}$ & $15.53^{\text {bc B }}$ \\
\hline & 8 & $14.33^{\mathrm{bA}}$ & $14.10^{\mathrm{bc} \mathrm{A}}$ & $15.15^{\mathrm{cB}}$ & $14.10^{\mathrm{b} \mathrm{A}}$ \\
\hline \multirow[b]{3}{*}{$\mathrm{pH}$} & 0 & $3.77^{\mathrm{aA}}$ & $3.77^{\mathrm{aA}}$ & $3.77^{\mathrm{a} \mathrm{A}}$ & $3.77^{\mathrm{aA}}$ \\
\hline & 2 & $3.88^{\mathrm{b} \mathrm{A}}$ & $3.91^{\mathrm{b} \mathrm{AB}}$ & $3.95^{\mathrm{b} A B}$ & $4.00^{\mathrm{b} \text { B }}$ \\
\hline & 4 & $4.11^{\mathrm{cA}}$ & $4.12^{\mathrm{cAB}}$ & $4.14^{\mathrm{cB}}$ & $4.17^{\mathrm{cC}}$ \\
\hline \multirow[t]{3}{*}{ Acidity (g malic acid. $100 \mathrm{~g}^{-1}$ ) } & 4 & $0.21^{\mathrm{cA}}$ & $0.19^{\mathrm{cB}}$ & $0.18^{\mathrm{cAB}}$ & $0.16^{\mathrm{cC}}$ \\
\hline & 6 & $0.14^{\mathrm{d} \mathrm{A}}$ & $0.13^{\mathrm{d} B}$ & $0.13^{\mathrm{dB}}$ & $0.13^{\mathrm{d} \mathrm{B}}$ \\
\hline & 8 & $0.09^{\mathrm{eA}}$ & $0.09^{\mathrm{e} A}$ & $0.09^{\mathrm{eA}}$ & $0.09^{\mathrm{eA}}$ \\
\hline \multirow{5}{*}{ Ascorbic acid (mg.100 g $\left.{ }^{-1}\right)$} & 0 & $14.69^{\mathrm{aA}}$ & $14.69^{\mathrm{a} A}$ & $14.69^{\mathrm{a} A}$ & $14.69^{\mathrm{a} A}$ \\
\hline & 2 & $14.21^{\mathrm{ab} \mathrm{A}}$ & $13.95^{\mathrm{bA}}$ & $13.91^{\mathrm{b} \mathrm{B}}$ & $13.78^{\mathrm{bB}}$ \\
\hline & 4 & $14.08^{\mathrm{bA}}$ & $14.04^{\mathrm{bA}}$ & $13.87^{\mathrm{b} \mathrm{B}}$ & $13.81^{\mathrm{bB}}$ \\
\hline & 6 & $13.98^{\mathrm{bA}}$ & $13.96^{\mathrm{bA}}$ & $13.96^{\mathrm{b} \mathrm{A}}$ & $13.94^{\mathrm{bA}}$ \\
\hline & 8 & $12.60^{\mathrm{cA}}$ & $12.43^{\mathrm{cA}}$ & $12.40^{\mathrm{cA}}$ & $12.10^{\mathrm{cA}}$ \\
\hline \multirow{2}{*}{ Reducing sugar (g.100 g-1) } & 0 & $8.39^{\mathrm{a}}$ & $8.39^{\mathrm{a}}$ & $8.39^{\mathrm{a}}$ & $8.39^{\mathrm{a}}$ \\
\hline & 2 & $8.96^{\mathrm{b}}$ & $8.89^{\mathrm{a}}$ & $9.14^{\mathrm{b}}$ & $9.55^{\mathrm{c}}$ \\
\hline Total sugar (g.100 g-1) & 8 & $10.23^{\mathrm{ab}}$ & $10.09^{\mathrm{ab}}$ & $9.93^{\mathrm{a}}$ & $9.76^{\mathrm{a}}$ \\
\hline \multirow{5}{*}{ Flesh firmness (kg) } & 0 & $8.06^{\mathrm{aA}}$ & $8.06^{\mathrm{aA}}$ & $8.06^{\mathrm{aA}}$ & $8.06^{\mathrm{aA}}$ \\
\hline & 2 & $6.61^{\mathrm{bA}}$ & $6.41^{\mathrm{bB}}$ & $6.33^{\mathrm{bB}}$ & $6.40^{\mathrm{bB}}$ \\
\hline & 4 & $5.52^{\mathrm{cA}}$ & $5.39^{\mathrm{c} A B}$ & $5.37^{\mathrm{cAB}}$ & $5.24^{\mathrm{cB}}$ \\
\hline & 6 & $4.40^{\mathrm{d} \mathrm{A}}$ & $4.38^{\mathrm{d} A B}$ & $4.35^{\mathrm{dAB}}$ & $4.08^{\mathrm{d} \mathrm{B}}$ \\
\hline & 8 & $3.61^{\mathrm{eA}}$ & $3.60^{\mathrm{eA}}$ & $3.57^{\mathrm{eA}}$ & $3.60^{\mathrm{eA}}$ \\
\hline
\end{tabular}

${ }^{\star}$ Values with same letters in a column are not significantly different $(\mathrm{p}>0.05){ }^{\star *}$ Values with the same letters in a row are not significantly different $(\mathrm{p}>0.05)$.

Higher flesh firmness values were obtained for the control sample, whereas the lowest flesh firmness values were obtained for the sample which was held for 24 hours prior to cold storage. Apples which were transported into cold storage rooms immediately after harvest, kept flesh firmness for 6 months. However, after the $8^{\text {th }}$ month of the storage, similar firmness values were obtained for all samples $(p>0.05)$. This indicates that the apple samples reached over-ripening levels at the $8^{\text {th }}$ month of the storage. To keep the flesh firmness of the samples unchanged, it was important to lower the oxygen content in a controlled atmosphere room while increasing the carbondioxide level to decrease oxidation reactions and reduce the metabolic activity (STREIF, 1985; CHU, 1986).
At the beginning of the cold storage period, the titratable acidity values of all samples were $0.30 \mathrm{~g}$ malic acid. $100 \mathrm{~g}^{-1}$. It was determined that the holding period did not show statistically significant changes in the acidity values of the samples prior to refrigerated storage $(p>0.05)$. At the end of the second month, the titratable acidity values of C, A- $-6, \mathrm{~A}-12$, and A-24 were recorded as $0.27,0.26,0.36$ and $0.22 \mathrm{~g}$ malic acid. $100 \mathrm{~g}^{-1}$, respectively. These values decreased at the end of the fourth month and became $0.21,0.19,0.18$ and 0.16 malic acid. $100 \mathrm{~g}^{-1}$, respectively. At the end of the 8-month refrigerated storage, the acidity values of all samples was $0.09 \mathrm{~g}$ malic acid. $100 \mathrm{~g}^{-1}$. The decrease in the acidity values of the samples 
are known to be related with the high metabolic activity and rapid maturity of the fruit (ERTAN et al., 1993).

The weight loss amount of the control samples at the end of the second month of storage was $0.98 \%$ when compared to their initial weight, whereas this value was $1.01 \%$ for A-6 and A-12, and $1.02 \%$ for A-24. No significant difference was observed for the weight loss values of the samples at the end of the second month of storage $(p>0.05)$. It was also determined that holding periods of the samples did not significantly affect the weight loss values of the samples $(p>0.05)$ in the second month of storage. At the end of the $8^{\text {th }}$ month of storage, weight loss values obtained for C, A-6, A-12, and A-24 were 3.63, 3.66, 3.62 and $4.02 \%$, respectively. The weight loss of the apples from all groups significantly increased during storage $(\mathrm{p}<0.05)$, but it was seen that the holding periods of the samples did not affect the weight loss values of the samples ( $p>0.05)$.

Peleg (1985) reported that weight losses of more than $5-10 \%$ cause significant wilting, low firmness, shriveling, and poor taste. In the present study, the weight loss of the samples was below the limit that determines poor quality. It has been reported that, a change in relative humidity would have a much larger effect at high than at low humidity (TU; NICOLAI; DE BAERDEMAEKER, 2000). However, in the present study, the apples were kept in relative humidity controlled chambers, in which the relative humidity was kept at a constant value. Therefore, lower weight loss was recorded during storage.

As seen in Table 1, at the end of the first two months of the storage period, the average titratable acidity value of the samples which were held for 24 hours (A-24) was lower than the others. At the end of the storage period of 8 months, it was determined by statistical analysis that there were no significant differences between the 4 samples in terms of total titratable acidity values $(\mathrm{p}>0.05)$. Data indicates that after the $8^{\text {th }}$ month of the storage period, the apples reached full maturity (CEMEROĞLU; ACAR, 1986).

During refrigerated storage, the vitamin $\mathrm{C}$ contents of all samples decreased continuously. The decrease in vitamin $\mathrm{C}$ contents of the samples was not found statistically significant at the end of the $2^{\text {nd }}, 4^{\text {th }}$, and $6^{\text {th }}$ months of storage $(p>0.05)$. On the other hand, after the $8^{\text {th }}$ month of storage, the decrease in the vitamin $C$ contents of the samples became statistically significant $(\mathrm{p}<0.05)$. In addition, there were significant differences between the decrease in the vitamin $\mathrm{C}$ contents of the samples which were held for 6,12 , and 24 months $(\mathrm{p}<0.05)$. The decrease in the vitamin $\mathrm{C}$ content of the sample which was held for 6 hours was lower than the decrease in the vitamin $C$ contents of the samples A-12 and A-24. It was understood that with the extended holding period, the loss in the vitamin $\mathrm{C}$ content of the sample was increased.

It was found that the storage period significantly affected the total sugar and reducing sugar contents of all samples $(\mathrm{p}<0.05)$. In the first 4 months of storage, total sugar and reducing sugar contents of all samples showed an increasing trend. It is thought that this increase is related with the degradation of starch to glucose and maltose (ERTAN et al., 1992). After the $6^{\text {th }}$ month of storage, total sugar and reducing sugar contents of the samples began to decrease. At the end of the $4^{\text {th }}$ month of storage, the starch levels in the apples were completely converted into glucose and maltose. Due to the extended storage period, maltose and glucose were spent because of the metabolic activity of the apples.

\section{Conclusion}

The results indicate that the holding period prior to storage had a significant effect on the changes in the chemical attributes of Starking Delicious variety apples during refrigerated storage at $0.5 \pm 1{ }^{\circ} \mathrm{C}$ under $90 \pm 1 \%$ relative humidity $(\mathrm{p}<0.05)$. The over-ripening of the samples which were not held prior to storage occurred slower than that of the other samples which were held for different periods. According to the results obtained in this study, it is suggested that apples should be cooled down to $0.5 \pm 1{ }^{\circ} \mathrm{C}$ and taken into refrigerated storage rooms immediately after harvest.

\section{References}

ABELES, F. B.; GHAGAN, H. E. Abscission: The role of ethylene, ethylene analogues, carbon dioxide and oxygen. Plant Physiology, v. 43, p. 1255-1258, 1968. PMid:16656908. PMCid:1087003. http:// dx.doi.org/10.1104/pp.43.8.1255

BURAK, M.; BÜYÜKYILMAZ, M.; ÖZ, F. Marmara bölgesi için ümitvar elma çeşitleri. Yalova Atatürk Bahçe Kültürleri Merkez Araştırma Enstitüsü Dergisi, v. 27, n. 1-2, p. 107-119, 1998.

CEMEROĞLU, B.; ACAR, J. Meyve ve Sebze İşleme Teknolojisi. H.Ü. Yayınları, 1986. 510 p.

CHU, C. L. Poststorage application of TAL prolong on apples from controlled atmosphere storage. Horticultural Science, v. 21, n. 2, p. 267-268, 1986.

COSETENG, M. Y.; LEE, C. Y. Changes in apple polyphenoloxydase and polyphenol concentrations in relation to degree of browning. Journal of Food Science, v. 52, n. 4, p. 985-989, 2006. http://dx.doi. org/10.1111/j.1365-2621.1987.tb14257.x

ERTAN, Ü.; ÖZELKÖK, S.; KAYNAŞ, K.; ÖZ, F. Bazı önemli elma çeşitlerinin normal ve kontrollü atmosferde depolanmaları üzerinde karşılaştırmalı araştırmalar. Bahçe, v. 21, n. 1-2, p. 77-90, 1992.

ERTAN, Ü.; ÖZELKÖK, S.; KAYNAŞ, K.; ÖZ, F. Marmara Bölgesinde yetiştirilen önemli elma çeşitlerinin normal ve kontrollü atmosferde muhafazaları üzerinde karşılaştırmalı araştırmalar. Yalova: Atatürk Bahçe Kültürleri Merkez Araştırma Enstitüsü, 1993. (Yayın, n. 11).

GÜNEL, T.; KARAÇALI, İ. Ege bölgesinde yetiştirilen Starking ve Golden Delicious elma çeşitlerinde uygun hasat zamanın saptanması. Ege Üniversitesi Ziraat Fakültesi Dergisi, v. 22, n. 3, p. 1-19, 1985.

HOEHN, E. et al. Efficacy of instrumental measurments for determination of minimum requirements of firmness, soluble solids, and acidity of several apple varieties in comparision to consumer expectations. Postharvest Biology and Technology, v. 27, n. 1, p. 27-37, 2003. http://dx.doi.org/10.1016/S0925-5214(02)00190-4

KARAÇALI, İ. Bahçe Ürünlerinin Muhafazası ve Pazarlanması. Bornova: E.Ü. Matbaası, 1993. 444 p. (Ege Üniversitesi Ziraat Fakültesi Yayınları, n. 494).

KAYNAŞ, K. Doğu Marmara bölgesinde yetiştirilen önemli elma çeşitlerinin depolama olanakları üzerine araştırmalar. Yalova, 1987. 266 p. 
KONOPACKA, D.; PLOCHARSKI, W. J. Effect of storage conditions on the relationship between apple firmness and texture acceptability. Postharvest Biology and Technology, v. 32, p. 205-211, 2004. http:// dx.doi.org/10.1016/j.postharvbio.2003.11.012

KOYUNCU, M. A.; ÇAVUŞOĞLU, Ş.; BAKIR, N. Van'da yetiştirilen bazı elma çeşitlerinin depolanması üzerine araştırmalar. In: BAHÇE ÜRÜNLERINDE MUHAFAZA VE PAZARLAMA SEMPOZYUMU, 1997, Yalova. Proceedings... Yalova, 1997. p. 323-328.

KOYUNCU,M. A.;EREN, İ.; DOLUNAY,E. Eğirdir(Isparta) koşullarında yetiştirilen bazı yeni elma çeşitlerinin soğukta muhafazası (I). In: ULUSAL BAHÇE BITKILERI KONGRESI, 4., 2003, Antalya. Proceedings... Antalya, 2003.

KUNDAKÇI, A. Gıdaların Soğukta Muhafazası. Uludağ Üniversitesi Ziraat Fakültesi Ders Notları, 1989. n. 39, 160 p.

LUTZ, J. M.; HARDENBURG, R. E. The commercial storage of fruits, vegetables and florist and nursery stocks. U.S. Department of Agriculture, 1997. 72 p. (Agricultural Handbook, n. 66).

ÖZ, F.; BULAGAY, A. Elma ve Elma Yetiştiriciliği. Yayın: Atatürk Bahçe Kültürleri Araştırma Enstitüsü Dergisi, 1986. n. 13.

ÖZBEK, S. Özel Meyvecilik. Adana: Çukurova Üniversitesi Ziraat Fakültesi Yayınları, 1978. 485 p.

ÖZCAN, M. Pozantı-Kamışılı Vadisinde yetiştirilen Amasya Starking ve Golden Delicious elmalarının muhafazası üzerine araştırmalar. Thesis (Doktora)-Çukurova Üniversitesi Fen Bilimleri Enstitüsü Bahçe Bitkileri Anabilim Dalı, Cukurova, 1990. 130 p.

ÖZELKÖK, S. et al. Bazı elma ve armut çeşitlerinde semperfresh kullanımının meyvelerin derim sonrası özelliklerine etkisi. Yalova: Atatürk Bahçe Kültürleri Araştırma Enstitüsü, 1992. 28 p.
PEKMEZCİ, M. Bazı önemli elma ve armut çeşitlerinin solunum klimakterikleri ve soğukta muhafazaları üzerine araştırmalar. 1975. $80 \mathrm{f}$. Thesis (Doctorate)-Tarım ve Orman Bakanlığı (Ministry of Forestery and Rural Affairs) Yayınları, Ankara,1975.

PELEG, K. Produce, Handling, Packaging and Distribution. Westport, Connecticut: The AVI Publishing Co. Inc., 1985.

PORRITT, S. W. Commerical Storage of Fruits and Vegetables. Ottowa: Department of Agriculture, 1976. (Publication, n. 1532).

RENFU, L.; GUYER, D. E.; BEAUDRY, R. M. Determination firmness and sugar content of apples using near-infrared diffuse reflectance. Journal of Texture Studies, v. 31, n. 6, p. 615-630, 2007.

SALUNKHE, D. K. 1974. Storage, processing and nutritional quality of fruits and vegetables. CRC Press Inc., 1974. 166 p.

STREIF, J. Quality parameters of apples as influenced by harvest date and storage conditions. In: WORKSHOP UNDER THE AGRO FOOD PROGRAMME OF THE STARTING COMITTEE FOR AGRİCUlTURAL RESEARCH, 1985, Dublin. Proceedings... Comission of European Communities, 1985. p. 64-67.

TU, K.; NICOLAI, B.; DE BAERDEMAEKER, J. Effects of relative humidity on apple quality under simulated shelf temparature storage. Scientia Horticulturae, v. 85, p. 217-229, 2000. http:// dx.doi.org/10.1016/S0304-4238(99)00148-X

TÜRKIYY. Tarım Bakanlığı İstatistikleri. 2004. Disponível em: $<$ http://www.tarim.gov.tr/istatistikler>.

TURQUİA. Disponível em: <http//www.tarim.gov.tr $>$. Acesso em: 2007. 